\title{
Introduction To Compilation Services As A Reinforcement Of Basic Accounting Concepts For Intermediate Accounting Students
}

Evelyn A. McDowell, Rider University, USA

Wei Li, Kent State University, USA

Karen McDougal, Saint Joseph's University, USA

\begin{abstract}
According to a recent survey of accounting firms in 2008, Compilation and write-up services make up $23 \%$ of accounting firm billing for small firms with less than \$1 Million in fee billings and 14\% overall for all types of firms (Anonymous 2008), yet accounting students are rarely exposed to these services in their accounting academic experience. This comprehensive case gives students an opportunity to develop proficiencies in providing accounting compilation and write-up services to small business clients. Specifically, the goals of the case are to help students review the steps of the accounting cycle, understand how each of the four basic financial statements are inter-related, improve their ability to prepare financial statements and related disclosures, and enhance their spreadsheet skills. This case has been classroom tested and is appropriate for an intermediate accounting; honors introduction financial accounting course; or an accounting information systems course.
\end{abstract}

Keywords: Compilations, Write-up Services, Accounting cycle, Accounting Disclosures

\section{INTRODUCTION}

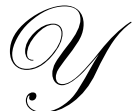

ou work as an entry level accountant for Daniel and Jacob, LLP, a regional accounting firm. Your firm is located in a large metropolitan market where there are many small to medium sized companies needing basic write-up services including: recording cash receipts and disbursements, accruals, and adjustments to produce a general ledger or trial balance; preparing financial statements from general ledger or trial balance; maintaining accounts receivable or accounts payable ledgers; calculating depreciation and maintaining fixed asset registers; processing payroll; calculating payroll tax deposits; preparing payroll tax returns; and summarizing data required for tax returns.

Mr. Wynn, the owner of Ewing Cleaning Services (ECS), approached the partners of Daniel and Jacob, LLP needing accounting services. After completing your firm's new client screening process, Ewing Cleaning Service, Inc. was accepted as a new client.

\section{COMPANY OVERVIEW}

Ewing Cleaning Services, Inc. (ECS) is a newly established C-corporation business. Eric Wynn, the only shareholder, started the business on August 1, 2009. His business provides office cleaning services for small to medium size businesses. In addition, Ewing Cleaning Services, Inc. sells cleaning products, at retail, to its customers and other small cleaning companies. ECS uses the accrual basis of accounting. The Company uses the perpetual inventory method for its merchandise inventory for products it sells to others, and uses the periodic inventory method for the Cleaning Supply Inventory. Due to the terms of a loan agreement with a local bank (a loan 
covenant), ESC must provide the bank with a complete set of accounting statements with full disclosures for the first three month of operations and once each quarter afterward.

\section{CLIENT SERVICES}

Partners of the firm prepared an engagement letter agreeing to provide financial statements in accordance with SSARS No. $1 .^{1}$ The nature of a compilation engagement involves presenting information, consisting of management's representations in the form of financial statements, without expressing assurance on them. The standards do not require accountants to make inquiries or perform other procedures to substantiate or review the information supplied by management. However, since the accountant has a direct association with the financial statements, there are responsibilities as detailed in SSARS No. 1 (AR 100).

SSARS No. 1 requires accountants who submit financial statements to clients or others, at a minimum, to compile those statements. However, whether accountants are required to issue a compilation report depends on the intended use of the financial statements. When the financial statements are intended for third-party use, accountants must issue a SSARS No. 1 compilation report. Since, ECS intends to submit the financial report to its bank, a thirdparty, Daniel and Jacob, LLC must issue a SSARS No. 1 compilation report.

After receiving a signed engagement letter from the client, Sue Ratcher, a senior level accountant at the firm, is assigned to the client. Sue visits the owner of ECS, Mr. Wynn, at his office and he gives her a list of transactions and background information about his company. You are assigned to work with Sue to complete this engagement. Your role is to perform the following tasks:

1. $\quad$ Record the transactions (See Appendix A);

2. Prepare a complete set of basic financial statements, including income statement, statement of retained earnings, classified balance sheet and statement of cash flows;

3. $\quad$ Prepare a draft of the compilation report (See Appendix B);

4. $\quad$ Prepare certain notes to financial statements; and

5. Prepare the title page for the financial report.

Figure 1: Screenshot of the Worksheet Students Use to Record Transactions

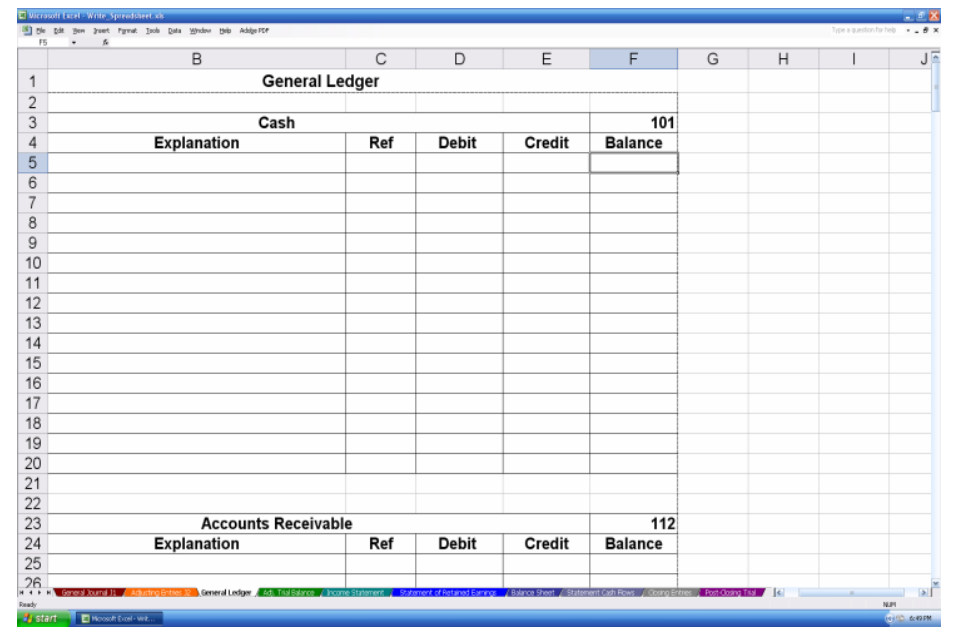

${ }^{1}$ For a complete background of compilations and SSARS, see Appendix D. 


\section{RECORDING THE TRANSACTIONS}

The transactions provided by the client are included in Appendix A. The firm uses a spreadsheet template to record the transactions and prepare the financial statements (See Figure 1). You must use this spreadsheet and link all numbers from the general journal entries to ensure that changes are automatically updated.

Sue tells you to use a standard chart of accounts for service companies (see Figure 1) and make modifications where necessary. The spreadsheet includes blank general ledgers for most of these accounts. If you must add additional accounts, be sure to add them in the order listed on the chart of accounts (see Figure 2). For example, if you need to add a property, plant, or equipment account, the next account number should be between 153 and 159.

Figure 2: Chart of Accounts

\section{Ewing Cleaning Supply Company}

Chart of Accounts

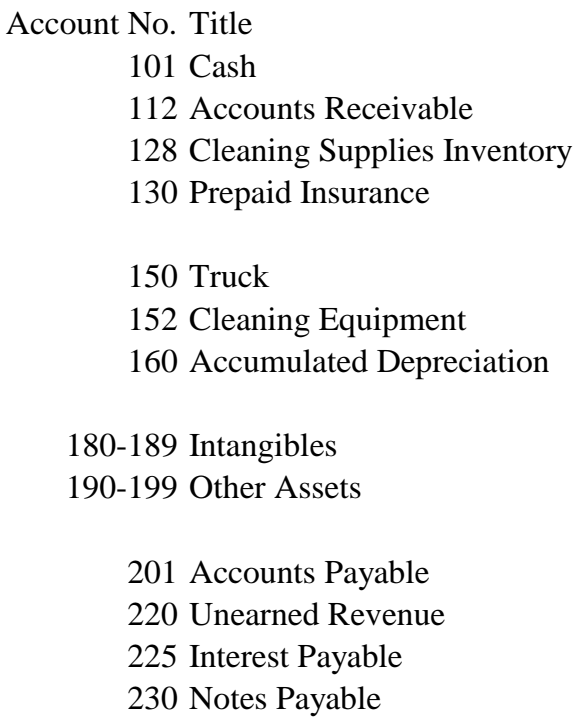

311 Common Stock

312 Additional Paid in Capital

320 Retained Earnings

332 Dividends

350 Income Summary

400 Service Revenue

401 Product Sales

630 Bank Service Charge

633 Gas and Oil Expense

634 Cleaning Supplies Expense

711 Depreciation Expense

722 Insurance Expense

725 Payroll Tax Epense

726 Salaries Expense

730 Interest Expense

735 Amortization Expense

\section{PREPARING BASIC FINANCIAL STATEMENTS}

Sue instructs you to use the multi-step approach for the Income statement and the indirect-approach for the Statement of Cash Flows. All financial statements should include proper headings and accounting symbolization, including dollar signs (first number in each column and totals), single line subtotals, and double line (bars) totals. For proper presentation of the financial statements, review the statements in recent accounting text books. In addition, each financial statement should include a note indicating the following: "See accompanying notes and accountants' report".

\section{PREPARING THE COMPILATION REPORT}

After finishing all the fieldwork, the Partner on the engagement believes that the firm can issue Ewing Cleaning Company, Inc. a full disclosure compilation report. Consequently, Sue asks you to prepare a draft of the report. An example is included in Appendix B. 


\title{
NOTES TO FINANCIAL STATEMENTS
}

According to APB Opinion No. 22 (FASB ASC 235-10-50-1), all significant accounting policies should be disclosed in its financial statements. The "Summary of Significant Accounting Policies," is considered to be included in the general category of notes to financial statements. In addition to other disclosures being prepared by others in the firm, the Sue has assigned you to the preparation the following disclosures for this client:

- $\quad$ Nature of the business - includes a description of the major products or services the reporting entity sells or provides. The disclosure also includes the entity's principal markets, including the locations of those markets. Additionally, if the entity operates in more than one business, disclosures must indicate the relative importance of each business and the basis for determining relative importance. Relative importance can be based on such things as assets, revenues, or net income, and does not have to be quantified. It can be communicated by using terms such as "predominantly," "about equally," or "major" (FASB 275-10-55-2).

- Inventories - the basis for stating inventories and the method of determining cost (ARB No. 43, Ch. 3A) (FASB ASC 210-10-50-1).

- Depreciation - a general description of the methods used in computing depreciation for major classes of depreciable assets (APB Opinion No. 12) (FASB ASC 360-10-50-1).

For guidance on the content of each disclosure, see the FASB Accounting Standards Codification related to each type of disclosure. The reference is indicated as (FASB ASC XXX-XX-XX-X) (see fasb.asc.org). In addition, present the notes to the financial statements in the following format:

\section{XYZ CORPORATION}

NOTES TO BALANCE SHEET

December 31, 20X3

\section{NOTE A-SUMMARY OF SIGNIFICANT ACCOUNTING POLICIES}

Nature of the business

Inventories

Property, Plant, and Equipment/Depreciation

Title Page Sue would also like you to prepare the title page for the financial report. The following is a guide for the title page:

\author{
XYZ CORPORATION \\ FINANCIAL STATEMENTS \\ One Month Ended December 31, 20X3
}

\section{DELIVERABLES}

The following items must be turned in to your instructor by the due date.
a. Title Page
b. Table of Contents, optional requirement
c. Accountant's Report (See Appendix B)
d. Basic Financial Statements
e. Notes to Financial Statements
f. Reflections (Answers to questions in Appendix D)
g. Support documents including general journal, general ledger, and adjusted trial balance
h. Spreadsheet file - email to professor/instructor 


\section{TEACHING NOTES}

The objectives of the case are to introduce write-up services, specifically compilation services; develop or improve spreadsheet computing skills; review accounting concepts from the principles of financial accounting course including identifying the steps in the accounting cycle, recording transactions in journals, posting to ledger accounts, and preparing a trial balance; prepare basic financial statements and closing entries; understand the relationships among various elements of the financial statements; understand how transactions affect the company's balance sheet; and understand how the financial statements are related to each other.

This case offers many benefits to accounting students. First, it is one of the first cases to introduce writeup/compilation services to accounting students. Since many students will work at regional and local firms, being exposed to these services as an undergraduate will give them added confidence on the job. Second, because it incorporates the entire accounting cycle including the preparation of the statement of cash flows, it provides a rare opportunity for students to see the "big picture". Third, the range of transactions depicted in the case helps the student recall or learn a broad range of entries needed to understand more complex accounting transactions. Fourth, using the spreadsheet to record transactions reinforces computing and technology skills.

These learning objectives are in response to the needs of the accounting profession. A recent survey of accounting firm employers indicated that one of the top three most desired attributes of accounting students is basic accounting skills (Kavanagh \& Drennan 2008). The case emphasizes these skills. Another high ranking attribute desired by employers from accounting students is improved written communication skills (e.g. Ashbaugh et al 2002; Rothenburg 2002). This case is also helps students focus on organizing their thoughts and writing coherently and succinctly.

The authors' experience indicates that, when used in an Intermediate Accounting course, the case should be assigned to students early in the course since many of the transactions are based on entries and accounting concepts learned in the first two accounting courses (Introductory Financial and Managerial Accounting). The case helps student review subjects covered in the later chapters of the Intermediate Accounting course which enhances learning throughout the term. The case should be equally as useful in a graduate level accounting theory course, as students at this level will have a solid understanding of GAAP, but may lack a full understanding of write-up services and how each statement relates to the others.

Before assigning the case, the instructor must consider three important factors. The first one is whether students should be given check figures. Check figures make grading the case easier and increase the pressure to "get the problem right." Unfortunately, providing check figures may also encourage academic dishonesty since students have a limited time to turn in the project as they attempt to balance to the check figures. On the other hand, not having the "right answers" is consistent with real business world. Therefore, the authors recommend not giving students check figures. Instead, the authors recommend giving students a chance to revise and resubmit their work until their work is matched with the instructor's solutions. For example, before submitting the final financial statements, students can be requested to submit their trial balances. In the accounting cycle, trial balances are needed to ensure that accountants are correct in recording transactions, posting transactions and summarizing the balances. Thus, trial balances are appropriate to check students' work. Specifically, the instructor can review students' trial balances and highlight the numbers that are wrong, if there are. After students revise their trial balances, they can resubmit their work until all the numbers are matched with the instructor's solutions before preparing the final statements. No grade points will be deducted for revising and resubmitting their work because students put forth effort to ensure the accuracy of their work. Also, the instructor can help students with their revisions.

The second factor is how to ensure students to work on the case independently, instead of simply copying each other's work or having someone else to do the work, etc. The authors recommend two ways. One way is to make very clear, at the beginning of the case that completing it is an independent work and no students are allowed to work together. Also, add additional assessment measures (i.e., questions on a test regarding the case, a separate in class quiz, etc) to ensure that each students become more proficient with the accounting concepts after they finish the case. The other way is to request students to use different numbers in some major transactions in the case. For 
example, students can be asked to use digits from their own student identification (ID) number in a transaction of sales on account. When different digits are used in the sales transaction, each student will produce different balances for accounts receivable and sales. Therefore, no students will have the same solutions for the case and thus cannot simply copy each other's work.

The third factor is how to provide students with examples of financial statement presentations. One way to provide the guidance is to tell the student to use the presentation of the statements in their accounting books. Most textbooks have excellent examples of financial statements instructors can refer to. Conversely, instructors can provide their own examples to the students.

The instructor should allow approximately 15 minutes of class time to introducing the case and the spreadsheet template. Students should be given at least two to three weeks to complete the case outside of class. The case material can be posted to the course website.

We estimate that each case will take about 10 minutes to grade, if the check figures are given. To facilitate grading, we have developed the answers to all questions. We will, upon request, include both a grading rubric for the instructor and "checklist" for the student. The rubric for the student is used to encourage the student to selfgrade and to meet all the requirements of the case before submitting it. All material, including the blank spreadsheet (.xls format) is available from the first author at no charge.

This case has been used in the beginning weeks of three Intermediate Accounting courses at the undergraduate level. Based on the feedback from students, the case is continually updated. During Spring 2009, we conducted formal feedback from 48 students enrolled in an Intermediate Accounting I course. Before completing the assignment, students reported lower ability to recall the accounting cycle (on a 1-5 scale with $1=$ no recall and 5 $=$ excellent recall $)(\mu=3.19)$, closing entries and their relationship to retained earnings $(\mu=3.04)$, preparation of the statement of retained earnings $(\mu=3.26)$ and the statement of cash flow $(\mu=2.50)$. They rated themselves highest in the ability to recall the basic accounting equation $(\mu=4.15)$.

After completing the assignment, students reported that they better understood all areas (on a 1-5 scale with $1=$ strongly disagree, $5=$ strongly agree), including the entire accounting cycle $(\mu=4.23)$, closing entries and their relationship to retained earnings $(\mu=3.98)$; and preparation of the statement of retained earnings $(\mu=4.06)$ and the statement of cash flow $(\mu=3.94)$. In addition, students believed the case increased their spreadsheet skills $(\mu=3.54)$. Overall, the students reported they believed the case was beneficial $(\mu=4.13)$. The average time students spent on the case was 5.7 hours.

\section{CONCLUSION}

Compilation and write-up services make up a significant portion of the accounting fees and revenues for many accounting firms, yet accounting students are rarely exposed to these services in their entire undergraduate education. This case is designed to introduce these services while giving students an opportunity to gain proficiencies in recording accounting transactions, preparing financial statements, completing the accounting cycle, analyzing the effect of financial activity, and writing and computing skills. The case has been tested in the classroom and, overall, students feel completing the case was beneficial.

\section{AUTHOR INFORMATION}

Evelyn McDowell is an assistant professor at Rider University. She is also a certified public accountant and has a MAcc and a Ph.D. in Accounting from Case Western Reserve University (Cleveland, Ohio). She obtained a bachelor of arts in business administration from Baldwin-Wallace College, in Berea Ohio. She teaches Accounting Principles, Intermediate Accounting, Managerial Accounting, and Governmental and Nonprofit Accounting. Prior to becoming an accounting professor, she owned and operated an accounting practice for over 15 years. In her practice, she specialized in small business and individual tax services; she also provided consulting services to nonprofit organizations. Dr. McDowell is a member of the AICPA, American Accounting Association, Institute of Internal Auditors, and Institute of Management Accountants. 
Wei Li is an assistant professor in the Department of Accounting at Kent State University, Kent, Ohio. She earned her Ph.D. in accounting from Washington State University in 2006. Wei has been teaching financial accounting and managerial accounting, and also been actively conducting research in these two areas. Her research work has appeared in premier accounting journals, including Accounting, Organization and Society, and Journal of Derivative Accounting. She is a frequent participant at meetings of the American Accounting Association, of which she is a member. Wei is a certified public accountant.

Karen McDougal, CPA, is a doctoral student from Temple University, where she is completing the requirements for the PhD.B.A. in Accounting. She is currently on faculty at Saint Joseph's University (Philadelphia, PA). She holds a B.B.A. in Accounting from Temple University and has earned an M.B.A. in Taxation from Widener University. Her teaching areas are Introductory Financial Accounting and Intermediate Financial Accounting. Her research interests include international accounting and auditing, corporate governance, and gender/diversity issues. Mrs. McDougal is a member of the American Accounting Association and the American Institute of Certified Public Accountants. She started her career in Public Accounting with the firm Laventhol \& Horwath, CPA's and later worked in financial reporting and internal auditing for such firms as Providian Financial, the Devereux Foundation and J.P. Morgan \& Co.

\section{REFERENCES}

1. Anonymous. 2008. Audit and Tax are still the "Income Stars" for CPA Firms. Accounting Office Management \& Administrative Report 08:1

2. Ashbaugh HK, Johnstone K, Warfield T. 2002. Outcome assessment of a writing-skill improvement initiative: Results and methodological implication. Issue in Accounting Education 17:123-48

3. Bailey L. 1996. Miller Compilation \& Reviews: Electronic Workpapers and Reference Guide. San Diego, CA: Harcourt Brace Professional Publishing

4. Kavanagh MH, Drennan. L. 2008. What skills and attributes does an accounting graduate need? Evidence from student perceptions and employer expectations. Accounting and Finance 48:279

5. Rothenburg E. 2002. How writing across the curriculum can be incorporated into accounting programs. The CPA Journal 72:14

\section{APPENDIX A: CLIENT TRANSACTIONS}

During August 2009, the following transactions, prepared by the client, were completed:

August Began his business by contributing a computer valued at $\$ 1,850$ and depositing $\$ 11,250$ in a checking 1 account in the name of the corporation in exchange for 3,500 shares, \$2 par value shares of common stock.

1 Received $\$ 6,000$ proceeds from an unsecured, $11 \%$, 5 year, interest only bank loan from Journey Bank, due August 1, 2014. The proceeds will be used to pay daily operations of the company. Interest will be paid monthly on the first of each month; next payment is due September $1^{\text {st }}$.

1 Paid $\$ 2,700$ for 3 floor waxer/buffer machines.

2 Purchased a used truck for $\$ 10,000$, paying $\$ 2,000$ cash and financing the balance with a $9 \%, 36$ month note from Journey Bank.

3 Purchased cleaning supplies for $\$ 3,500$ on account. These supplies will not be resold - use the Cleaning Supplies Inventory account.

3 Paid cash for an exclusive 3 yr right to sell cleaning products from Brite N' Clean Supply company, $\$ 1,500$.

3 Purchased 50 cans of cleaning product, XB4, on account, for resale purposes only, from Brite N' Clean, terms $2 / 15$, net 30 . Each can costs $\$ 8.00$. Total shipping costs were $\$ 15.00$, also included in the amount owed. Invoice total, $\$ 415.00$ - use the Merchandise Inventory Account.

5 Paid $\$ 2,400$ on a one-year insurance policy, effective August 1.

$7 \quad$ Hired 2 workers at $\$ 8.50$ per hour.

8 Jim Bob Grocery Store paid Eric $\$ 1,800$ in advance for six months of cleaning services to be performed monthly, at the end of every month. The monthly charge to Jim Bob Grocery is $\$ 300$. The work is to begin this month. 
10 Paid Brite N' Clean for products purchased on August 3rd, less discount. Discount is applied to the total invoice (including shipping costs).

12 Billed customers $\$ 6,300$ for cleaning services performed.

15 Paid gas and oil for the month on the truck, $\$ 525$.

18 Paid $\$ 600$ of amount owed on cleaning supplies.

18 Purchased 30 cans of cleaning product, XB4, \$261, for resale purposes only on account. Each can cost $\$ 8.20$, plus total shipping costs of $\$ 15.00$.

18 Paid $\$ 800.00$ to employees, with withholding of $\$ 70.00$ for federal income taxes, $\$ 24$ for state income taxes, $\$ 49.60$ for social security (FICA) tax, $\$ 11.60$ for Medicare tax, and $\$ 16.00$ for city income tax.

18 Accrue employer tax (related to August $18^{\text {th }}$ payroll of $\$ 112.00$ ). These taxes include employer portion of FICA and Medicare tax and state and federal unemployment tax. Use Employer Tax Payable account.

21 Collected $\$ 4,400$ from customers billed on August 12.

22 Sold 20 cans of cleaning product, XB4, to T. Jones Cleaning on account for $\$ 20.00$ each. Ewing Cleaning Services, Inc. uses a perpetual inventory system for its merchandise inventory sales and determines costs using first in-first out costing method.

24 Using Mr. Wynn's credit card, purchased a used cleaning cart used to carry cleaning supplies to each office, $\$ 300$.

25 Billed customers $\$ 6,500$ for cleaning services.

31 Bank returned a check for $\$ 125$ from a customer, Tang Juice Company, for services paid on August $21^{\text {st }}$. The bank charges Ewing Cleaning Services a $\$ 5.00$ service fee for the NSF check.

31 Paid withholding tax for August $18^{\text {th }}$ payroll, including employer tax.

31 Sold one of the floor waxer/buffer machines purchased on August 1 for $\$ 850$. Record all depreciation related to this equipment up to the date of the sale.

31 Declared and paid a $\$ .50$ per share cash dividend.

After talking with the client, Sue identified the following information related to August transactions. You must record any additional transactions as adjusting entries, based on this new information:

1. A review of office documents revealed that earned but unbilled fees at August 31 were $\$ 1,475$.

2. All equipment is depreciated over 5 years, using the straight line method.

3. An inventory count shows $\$ 800$ of cleaning supplies (not for resale) on hand at August 31.

4. Record the amortization of the franchise.

5. Accrued but unpaid employee salaries were $\$ 1,000$ with withholding of $\$ 150.00$ for federal income taxes, $\$ 32$ for state income taxes, $\$ 62$ for social security (FICA) tax, $\$ 14.50$ for Medicare tax, and $\$ 20.00$ for city income tax.

6. Accrued employer payroll tax of $\$ 112.00$ related to the above payroll. Use the Employer Tax Payable account to record all employer tax liabilities.

7. Record the interest incurred on both note payables for the month.

8. Record the income earned from the Jim Bob Grocery Store account.

9. One-twelfth of the insurance expired.

10. Accrue income taxes for the period. The company expects to pay income taxes at a $34 \%$ rate.

\section{APPENDIX B: COMPILATION REPORT_CORPORATION, ACCRUAL BASIS, STANDARD}

To the Board of Directors

XYZ Company

City, State

I (We) have compiled the accompanying balance sheet of XYZ company (a corporation) as of September 30, 20X3, and the related statements of income and retained earnings and cash flows for the year then ended, in accordance with Statements on Standards for Accounting and Review Services issued by the American Institute of Certified Public Accountants 
A compilation is limited to presenting in the form of financial statements information that is the representation of management (the owners). I (We) have not audited or reviewed the accompanying financial statements and, accordingly, do not express an opinion on any other form of assurance on them.

\section{Firm Signature}

Report Date

Note: The report date is generally the date of completion of the accountant's work. Use the day you complete this assignment as the report date.

Source: AICPA, AR100.16

\section{APPENDIX C: OVERVIEW OF COMPILED AND REVIEWED STANDARDS}

The Statements on Standards for Accounting and Review Services (SSARS), issued by the American Institute of Certified Public Accountants (AICPA), are a series of statements designed to give the accountant guidance on non audit engagements. Prior to the issuance of Statements on Standards for Accounting and Review Services (SSARS), the accounting profession had two options with respect to assurance services: perform an audit or provide no assurance on the financial statements. The business community was not well served with the two options, since third-parties wanted the CPA to take some responsibility for accuracy of the statements. As a result, the AICPA developed two new types of non-audit engagements: compilations and reviews (Bailey 1996).

\section{Historical Background}

With the conviction of a CPA firm of negligence in the preparation of financial statements for a tenant corporation (1136 Tenant's Corporation v. Max Rothenburg and Company [30 N.Y. 2d 585, 330 N.Y.S. $2 d 800$ (1972)], the AICPA created the Accounting and Review Services (ARSC). The ARSC was granted authority to establish standards to help guide public accountants in the conduct of non audit engagements for their nonpublic accountants. In 1978, the ARSC issued the first SSARS. As of June 2009, there are 10 standards and several interpretations.

\section{General Responsibilities of a Compilation Engagement}

Since the underlying information used to prepare the financial statements are the representation of management (owners). According to SSARS No. 1, (AICPA, AR 100.10), the standards do not require the accountant to inquire or perform procedures to "verify, corroborate, or review the information submitted by the client". Therefore, the accountant does not offer any form of assurance on the financial statements. The basic steps in compiling financial statements include the following:

$\quad$ Establishing an understanding with the client regarding the services to be performed;

$\square \quad$ Acquiring an adequate understanding of accounting principles and practices used in the client's industry;

․ Developing a general understanding of the nature of the client's business transactions;

$\square \quad$ Developing a general understanding of the form of the client's accounting records;

․ Developing a general understanding of the client's accounting expertise and the stated qualifications of the accounting personnel;

$\square \quad$ Developing a general understanding of the form and content of the client's financial statements and the accounting basis on which they are to be presented;

Reading the client's financial statements to consider whether they appear to be appropriate in form and free of material error; and 
Obtaining Additional or revised information if information from the client was incorrect, incomplete, or otherwise unsatisfactory. (AICPA, AR 100)

\section{Nature of a Review engagement}

A review engagement has two phases. In Phase I, the accountant, through inquiry and analytical procedures, gathers a limited amount of data to determine whether the client's financial statements are in accordance with GAAP. The second phase, based on the data gathered in phase I, the CPA issues a report giving limited assurance on the financial statements. The steps used to complete a review engagement are similar to the steps performed in a for compilation engagement however, the CPA is required to make certain inquiries and perform appropriate analytical procedures.

\section{APPENDIX D: REFLECTIVE THINKING ESSAY QUESTIONS}

1. List the accounting cycle steps you used to complete this assignment (use correct terminology, where applicable).

2. Did the two loans affect the balance sheet of ECS, Inc? If so, how?

3. How did the economic entity assumption affect the financial statements of ESC, Inc.?

4. Explain the difference between accumulated depreciation and depreciation expense? How does recording depreciation affect the balance sheet, in general?

5. Why are adjusting entries necessary? Include in your discussion any applicable accounting principles and assumptions.

6. Did you find a difference between the balances of retained earnings on the adjusted trial balance and post closing trial balance? If so, explain why the difference.

7. With respect to ESC answer the following questions,

a. Explain why there are differences between income from operations, net income, and cash provided (used) from operations?

b. Which do you think should be used as a basis for future projections of earnings for ESC and why?

c. Defend an alternative answer given to $7 \mathrm{~b}$.

8. Based on your work with ESC, in general terms, how does the statement of cash flows relate to the balance sheet?

9. Why are disclosures necessary? Why do you think the bank required them?

10. You are having lunch with a friend who tells you he started a business and needs a set of financial statements prepared by an accountant to present to a major supplier but is reluctant to pay for an audit. How would you explain the benefits of compilation services to him? 